\title{
The Impact of Personal and Institutional Investor Sentiment on Stock Returns under the Chinese Stock Market Crash
}

\author{
Kexuan Wang \\ Shanghai University, China \\ *wang1ke2xuan@126.com
}

\begin{abstract}
Under Chinese stock market crash, personal and institutional investor sentiment is out of control, which leads to the stock prices fall further. Therefore this article uses the concept of behavioural finance to study the problem. This essay uses multiple regressions to study the influence of the current and lagged emotions of individuals and institutions on the stock returns. The conclusion is helpful to solve the stock market crash and improve the economy in China.

Keywords: stock market crash, individual investor sentiment, institutional investor sentiment, multi-factors pricing model
\end{abstract}

\section{Introduction}

The stock market crash happened in 2015 made the investors suffer a lot. Stock prices decreased sharply and thousands of stocks fell in lock step. Individual and institutional investor sentiment was out of control, and they sold the shares, which leaded to the stock prices fall further. However, the measures taken by government had no effect. Thus, focusing on stock market crash occurred in 2008, this essay studies the impact of personal and institutional investor sentiment on stock yields.

Foreign scholars began to explore this area in the 1990s, and mainly focused on the existence of internal mechanism between investor sentiment and stock yields. They created different theoretical models to explain the internal mechanism, including DSSW model [1]. BSV model [2], DHS model [3] and HS model [4]. Both Chinese and foreign scholars conducted empirical exploration based on the theoretical mechanisms. Wang et al. (2006) examined the effective use of investor sentiment to predict stock returns volatility with GARCH model [5]. Wang and Liu (2011) paid close attention to the Bull and Bear, and found that at the bear market, investor sentiment affected stock returns more deeply than that at bull market [6]. When selecting sentiment proxies, there are mainly two ways. Foreign scholars usually uses direct way to express personal and institutional investor sentiment [7]. By contrast, domestic scholars both use direct and indirect ways $[8,9]$.

\section{Experimental}

\subsection{Theoretical Derivation}

Ross (1976) believed that factors that affect capital asset pricing are not only the market portfolio return, but also a variety of factors. After, Ross proposed arbitrage pricing model [10].

expected return $=\beta_{1} * E\left(r_{\text {factor } 1}\right)+\beta_{2} * E\left(r_{\text {factor } 2}\right)++\cdots+\beta_{n} * E\left(r_{\text {factorn }}\right)+\varepsilon$

Chinese stock market is an imperfect market, so the fluidity of information is very slow, which means investors cannot always remain rational as well as choose efficient portfolio. Thence, the factors that affect investor sentiment should be added into asset pricing model. Moreover, it is 
necessary to divide sentiment into 2 parts. Furthermore, academics believe that in China, the government prefer to carry out human intervention in the stock market which leads to the volatility of stock market price. Therefore, macro variables are added into equation.

$\mathrm{R}_{P}=r_{f}+\beta_{1} * E\left(\right.$ sentiment $\left._{\text {personal }+ \text { institutional }}\right)+\beta_{2} * E($ macrovariables $)+\varepsilon$

\subsection{Proposing Hypotheses}

Focusing on sentiment $t_{\text {personal+institutional }}$ and $\mathrm{R}_{P}$, the study wants to concern the impact of individual and institutional investor sentiment on stock market returns before and after the crash. Meanwhile, the paper plans to divide time dimension into current and lag time.

Then this article puts forward 5 hypotheses. Assumption 1: Before crash, individual and institutional investor sentiment has a positive impact on the current market returns. After crash, the influence will be weakened. Assumption 2: In the current relationship, the degree of the individual and institutional investors sentiment affect the overall rate of return is asymmetric. Assumption 3 : lag individual and institutional investor sentiment negatively affect the stock returns and after stock market crash, the ability to predict market yields will be weakened. Assumption4: the asymmetry still exists in the lag relationship. Assumption 5: the macroeconomic variables are positively correlated with stock market returns insignificantly under every situation.

\subsection{Variables Selection}

For the selection of investor sentiment, this essay chooses to use new accounts of individual and institutional investors because this data is more accurate and reliable.

Figure 1 - Selection \& source of variables

\begin{tabular}{|l|l|l|}
\hline variables & symbols & sources \\
\hline Stock market returns & Shr & GTA \& Hong Kong University database \\
\hline Individual investor sentiment & sent $_{p}$ & China securities clearing firm \\
\hline Institutional investor sentiment & sent $_{i}$ & China securities clearing firm \\
\hline Growth rate of industrial added-value & Indgdp $\%$ & GTA \\
\hline Money supply & $\mathrm{M} 1-\mathrm{M} 2$ & GTA \\
\hline Inflation rate & Inflation & GTA \\
\hline Macroeconomic prosperity index & EXI\% & State Statistics Bureau \\
\hline
\end{tabular}

\subsection{Experimental Design}

Based on the five assumptions, the paper made an experimental design. To test the assumption 1, $2 \& 5$, this paper uses OLS regression to link Individual and institutional investor sentiment and macroeconomic variables to the stock returns before and after stock crash. The lag stock returns are also considered here.

$$
\begin{aligned}
& \operatorname{Shr}_{t}=\beta_{0}+\beta_{1} * \operatorname{sent}_{t}^{p}+\beta_{2} * \operatorname{Indgdp}_{t}+\beta_{3} *(M 1-M 2)_{t}+\beta_{4} * \text { inflation }_{t}+\beta_{5} *{\text { EXI } \%_{t}+\beta_{6} *} \\
& \operatorname{shr}(-1)+\varepsilon_{t} \\
& \operatorname{Shr}_{t}=\beta_{0}+\beta_{1} * \operatorname{sent}_{t}^{i}+\beta_{2} * \operatorname{Indgdp}_{t}+\beta_{3} *(M 1-M 2)_{t}+\beta_{4} * \text { inflation }_{t}+\beta_{5} * E X I \%_{t}+\beta_{6} * \\
& \operatorname{shr}(-1)+\varepsilon_{t}
\end{aligned}
$$

To test the assumption 3, 4\&5, the lag time is divided into short term, middle term and long term.

$$
\mathrm{Shr}_{t}=\beta_{0}+\beta_{1} * \operatorname{sent}_{t-\mathrm{n}}^{p}+\beta_{2} * \operatorname{Indgdp}_{t}+\beta_{3} *(M 1-M 2)_{t}+\beta_{4} * \text { inflation }_{t}+\beta_{5} *{\text { EXI } \%_{t}}_{t}+\beta_{6} *
$$$$
\operatorname{shr}(-1)+\varepsilon_{t}
$$ 


$$
\begin{aligned}
& \operatorname{Shr}_{t}=\beta_{0}+\beta_{1} * \operatorname{sent}_{t-\mathrm{n}}^{i}+\beta_{2} * \operatorname{Indgdp}_{t}+\beta_{3} *(M 1-M 2)_{t}+\beta_{4} * \text { inflation }_{t}+\beta_{5} * \text { EXI\% }_{t}+\beta_{6} * \\
& \operatorname{shr}(-1)+\varepsilon_{t}
\end{aligned}
$$

$\mathrm{N}=1,2$ (short term); $\mathrm{N}=6$ (middle term); $\mathrm{N}=10$ (long term)

\section{Results and Discussion}

The paper intends to use OLS model to explore the current relationship as shown before and the regression results are presented as follows.

\begin{tabular}{|c|c|c|c|c|c|c|c|}
\hline \multicolumn{4}{|c|}{ Before stock crash (2006.01 2007.12) } & \multicolumn{4}{|c|}{ After stock crash (2008.01 2013.12) } \\
\hline \multicolumn{2}{|c|}{$\begin{array}{l}\text { Personal investor } \\
\text { sentiment }(1)\end{array}$} & \multicolumn{2}{|c|}{$\begin{array}{l}\text { Institutional investor } \\
\text { sentiment }(2)\end{array}$} & \multicolumn{2}{|c|}{$\begin{array}{l}\text { Personal investor } \\
\text { sentiment }(3)\end{array}$} & \multicolumn{2}{|c|}{$\begin{array}{l}\text { Institutional investor } \\
\text { sentiment }(4)\end{array}$} \\
\hline sent $_{p}$ & $\begin{array}{c}0.083 \\
\left(2.485^{\star *}\right)\end{array}$ & sent $_{i}$ & $\begin{array}{c}0.008 \\
(0.118)\end{array}$ & sent $_{p}$ & $\begin{array}{c}0.027 \\
(1.368)\end{array}$ & sent $_{i}$ & $\begin{array}{c}0.003 \\
(0.179)\end{array}$ \\
\hline c & $\begin{array}{c}0.043 \\
(1.714)\end{array}$ & c & $\begin{array}{l}0.046 \\
(1.54)\end{array}$ & c & $\begin{array}{l}-0.013 \\
(-1.289)\end{array}$ & c & $\begin{array}{l}-0.011 \\
(-1.06)\end{array}$ \\
\hline$d($ Indgdp\%) & $\begin{array}{c}-0.529 \\
(-0.599)\end{array}$ & $d(\operatorname{lndgdp} \%)$ & $\begin{array}{c}0.321 \\
(0.333)\end{array}$ & d(Indgdp\%) & $\begin{array}{c}0.893 \\
\left(1.91^{*}\right)\end{array}$ & $d($ Indgdp\%) & $\begin{array}{c}0.958 \\
\left(2.02^{* *}\right)\end{array}$ \\
\hline d(M1-M2) & $\begin{array}{l}-0.360 \\
(-0.185)\end{array}$ & $\mathrm{d}(\mathrm{M} 1-\mathrm{M} 2)$ & $\begin{array}{c}1.029 \\
(0.455)\end{array}$ & d(M1-M2) & $\begin{array}{c}0.648 \\
(1.135)\end{array}$ & $\mathrm{d}(\mathrm{M} 1-\mathrm{M} 2)$ & $\begin{array}{l}0.722 \\
(1.25)\end{array}$ \\
\hline Inflation & $\begin{array}{c}2.974 \\
(0.764)\end{array}$ & Inflation & $\begin{array}{c}3.498 \\
(0.764)\end{array}$ & Inflation & $\begin{array}{c}1.152 \\
(0.598)\end{array}$ & Inflation & $\begin{array}{c}0.086 \\
(0.047)\end{array}$ \\
\hline EXI\% & $\begin{array}{c}4.814 \\
(0.488)\end{array}$ & EXI\% & $\begin{array}{c}11.07 \\
(0.806)\end{array}$ & EXI\% & $\begin{array}{c}2.246 \\
(1.223)\end{array}$ & EXI\% & $\begin{array}{c}2.45 \\
(1.32)\end{array}$ \\
\hline Shr $(-1)$ & $\begin{array}{c}-0.257 \\
(-0.995)\end{array}$ & Shr $(-1)$ & $\begin{array}{l}-0.152 \\
(-0.505)\end{array}$ & Shr $(-1)$ & $\begin{array}{l}-0.201 \\
\left(-1.68^{*}\right)\end{array}$ & Shr $(-1)$ & $\begin{array}{c}-0.17 \\
(-1.38)\end{array}$ \\
\hline R square & $36.57 \%$ & $\mathbf{R}$ square & $12.16 \%$ & R square & $16.93 \%$ & R square & $14.58 \%$ \\
\hline
\end{tabular}

Figure 2 - OLS results of the stock crash for current relations

To test assumption 1, though observing (1) (2) (3) (4), the coefficients of sentiment are positive, which proves the first half of hypothesis 1 is correct. At the same time, compared to (1) (2), the value of coefficients in (3) \& (4) are decreased, which confirmed the second half of hypothesis 1. About testing assumption 2, the $\mathrm{t}$ value and $\mathrm{R}$ square of personal investor sentiment are higher than those of institutional sentiment. Thus, assumption 2 is right and personal investor sentiment is dominant. The coefficients of macro variables are positive, which is same as the results of assumption 5. While after the stock crash, growth rate of industrial added-value is significantly related to stock price. As a result, assumption 5 is proved incompletely.

Moreover, the paper studies the lagged relations to test assumption 3, 4 \& 5 . 
Figure 3-Effect of lagged personal investor sentiment on returns before the stock crash

\begin{tabular}{|c|c|c|c|c|c|c|c|c|c|}
\hline & (9) & (10) & (11) & (12) & & (13) & (14) & (15) & (16) \\
\hline $\operatorname{sent}_{-1}^{p}$ & $\begin{array}{c}0.035 \\
(0.875)\end{array}$ & & & & $\operatorname{sent}_{-1}^{i}$ & $\begin{array}{l}0.024 \\
(0.402)\end{array}$ & & & \\
\hline sent $_{-2}^{p}$ & & $\begin{array}{l}-0.038 \\
(-1.16)\end{array}$ & & & sent $_{-2}^{i}$ & & $\begin{array}{l}-0.077 \\
(-1.44)\end{array}$ & & \\
\hline $\operatorname{sent}_{-6}^{p}$ & & & $\begin{array}{l}0.0186 \\
(0.37)\end{array}$ & & $\operatorname{sent}_{-6}^{i}$ & & & $\begin{array}{l}0.052 \\
(0.81)\end{array}$ & \\
\hline $\operatorname{sent}_{-10}^{p}$ & & & & $\begin{array}{l}-0.0397 \\
(-0.59)\end{array}$ & $\operatorname{sent}_{-10}^{i}$ & & & & $\begin{array}{l}-0.0397 \\
(-0.441)\end{array}$ \\
\hline C & $\begin{array}{c}0.036 \\
(1.175)\end{array}$ & $\begin{array}{l}0.063 \\
\left(1.97^{\star}\right)\end{array}$ & $\begin{array}{l}0.0457 \\
(1.02)\end{array}$ & $\begin{array}{l}0.071 \\
(1.19)\end{array}$ & c & & $\begin{array}{l}0.067 \\
\left(2.12^{\star}\right)\end{array}$ & $\begin{array}{l}0.0415 \\
(1.01)\end{array}$ & $\begin{array}{l}0.074 \\
(1.14)\end{array}$ \\
\hline $\begin{array}{c}\text { d(Indg } \\
\text { dp\%) }\end{array}$ & $\begin{array}{c}0.484 \\
(0.505)\end{array}$ & $\begin{array}{l}1.079 \\
(0.752)\end{array}$ & $\begin{array}{l}0.8999 \\
(0.46)\end{array}$ & $\begin{array}{l}0.719 \\
(0.25)\end{array}$ & $\begin{array}{l}d(\text { Indg } \\
\text { dp\%) }\end{array}$ & $\begin{array}{l}0.421 \\
(0.424)\end{array}$ & $\begin{array}{l}1.730 \\
(1.14)\end{array}$ & $\begin{array}{c}1.155 \\
(0.591)\end{array}$ & $\begin{array}{l}0.051 \\
(0.02)\end{array}$ \\
\hline $\begin{array}{l}\text { d(M1- } \\
\text { M2) }\end{array}$ & $\begin{array}{l}1.8126 \\
(0.796)\end{array}$ & $\begin{array}{c}1.253 \\
(0.548)\end{array}$ & $\begin{array}{l}1.826 \\
(0.54)\end{array}$ & $\begin{array}{l}0.513 \\
(0.14)\end{array}$ & $\begin{array}{l}\text { d(M1- } \\
\text { M2) }\end{array}$ & $\begin{array}{c}1.164 \\
(0.536)\end{array}$ & $\begin{array}{l}1.835 \\
(0.83)\end{array}$ & $\begin{array}{r}1.385 \\
(0.495)\end{array}$ & $\begin{array}{l}0.423 \\
(0.11)\end{array}$ \\
\hline $\begin{array}{c}\text { Inflatio } \\
\mathbf{n}\end{array}$ & $\begin{array}{l}5.3795 \\
(1.08)\end{array}$ & $\begin{array}{r}2.393 \\
(0.471)\end{array}$ & $\begin{array}{l}1.616 \\
(0.26)\end{array}$ & $\begin{array}{l}1.6999 \\
(0.22)\end{array}$ & $\begin{array}{c}\text { Inflati } \\
\text { on }\end{array}$ & $\begin{array}{c}4.307 \\
(0.864)\end{array}$ & $\begin{array}{l}2.164 \\
(0.44)\end{array}$ & $\begin{array}{l}1.323 \\
(0.22)\end{array}$ & $\begin{array}{l}0.653 \\
(0.08)\end{array}$ \\
\hline EXI\% & $\begin{array}{l}10.202 \\
(0.924)\end{array}$ & $\begin{array}{l}15.737 \\
(1.374)\end{array}$ & $\begin{array}{l}16.263 \\
(0.85)\end{array}$ & $\begin{array}{l}12.433 \\
(0.48)\end{array}$ & EXI\% & $\begin{array}{c}10.28 \\
(0.866)\end{array}$ & $\begin{array}{l}16.12 \\
(1.44)\end{array}$ & $\begin{array}{l}12.892 \\
(0.78)\end{array}$ & $\begin{array}{c}10.90 \\
(0.422)\end{array}$ \\
\hline $\operatorname{Shr}(-1)$ & $\begin{array}{l}-0.284 \\
(-0.865)\end{array}$ & $\begin{array}{l}-0.182 \\
(-0.60)\end{array}$ & $\begin{array}{l}-0.2468 \\
(-0.54)\end{array}$ & $\begin{array}{l}-0.137 \\
(-0.26)\end{array}$ & $\begin{array}{l}\text { Shr } \\
(-1)\end{array}$ & $\begin{array}{l}-0.154 \\
(-0.515)\end{array}$ & $\begin{array}{l}-0.227 \\
(-0.8)\end{array}$ & $\begin{array}{l}-0.144 \\
(-0.35)\end{array}$ & $\begin{array}{l}-0.122 \\
(-0.229)\end{array}$ \\
\hline $\mathbf{R}^{2} \%$ & 16.10 & 20.17 & 10.01 & 7.61 & $\mathbf{R}^{2} \%$ & 12.96 & 23.62 & 14.01 & 5.70 \\
\hline
\end{tabular}

Form figure 3, the article can conclude short-term personal investor sentiment is connected to stock yields ambiguously. Middle-term personal investor sentiment negatively predicts returns while long-term predicts returns positively. The lagged institutional investor sentiment is not always negatively linked to stock returns. To conclude, assumption 3 is rejected. Lagged institutional investor sentiment has a stronger capability to reflect stock returns before the stock market crash by comparing coefficients and $\mathrm{R}$ square of personal and institutional investor sentiment. Assumption 4 is partial proved. Then, the essay study the effect of lagged personal and institutional investor sentiment on returns after the crash. The empirical results show that hypothesis 3 is wrong by observing the sign before the coefficients of investor sentiment. Furthermore, $\mathrm{R}$ square and coefficients' value prove that after the stock crash, personal investor sentiment is more convinced to 
predict market yields than institutional investor sentiment. Assumption 4 is verified. Similarly, assumption 5 is found to be incorrect.

\section{Conclusions and Suggestions}

In conclusion, the current investor sentiment is positively related to stock returns, and after the crash, this positive correlation weakens. Besides, investor sentiment and expected stock returns have a different link in short, medium and long term both before and after the crash. Thirdly, the growth rate of industrial added value is linked to stock returns significantly after the stock crash. Then comparing two kinds of investor sentiment, individual and institutional investor sentiment responds to stock market return asymmetrically before and after the crash.

Three suggestions are raised to manage sentiment to save the crash for Chinese government. The government should guide both personal and individual investors to invest reasonably. Furthermore, adjusting the ratio of personal and individual investors is also important. Lastly, government should take good use of macroeconomic policies. With these suggestions, the government can solve the stock crash easily and the economy will therefore be improved.

\section{References}

1. J. B. Delong, A. Shleifer, L. Summers, etal. Noise trader risk in financial markets, Journal of Positive Economy, vol. 98, pp.703-748, (1990).

2. N. Barberis, A. Shleifer, R. Vishny, A model of investor sentiment, Journal of Financial Economics, vol.49, pp.307-343, (1998).

3. K. DanieL, D. Hirshleifer, A. Subrahmanyam, Investor psychology and security market under- and over- reaction, Journal of Finance, vol.53, pp.1839-1885, (1998).

4. H. Hong, J. C. Stein, A unified theory of under-reaction, momentum trading, and overreaction in asset markets, Journal of Finance, vol.54, pp.2143-2184, (1999).

5. Y. Wang, A. Keswani, S. J. Taylor, The relationship between sentiment, returns and volatility, International Journal of Forecasting. vol.22, pp.109-123, (2006).

6. Y. R. Wang, S.C. Liu, Investor sentiment and stock returns: bull and bear market \& US comparison and contrast, Journal of Beijing University of Aeronautics and Astronautics (Social Sciences Edition). vol.24, pp.74 -80, (2011).

7. R. Verma, H. Baklaci, G. Soydemir, The impact of rational and irrational sentiments of individual and institutional investors on DJIA and S\&P500 index returns, Applied Financial Economics. vol.18, pp.1303-1317, (2008).

8. Q. Zhang, S. E. Yang, H. Yang, An empirical study of Chinese stock market investor sentiment and stock Returns, Systems Engineering, vol.25, pp.13 -17, (2007). 
9. W. Q. Liu, X. X. Liu, Individual and institutional investor sentiment and stock returns based on the research of Shanghai A-share market, Journal of Management Sciences in China, vol. 17 , pp.70 $-87,(2014)$.

10. S. A. Ross, The arbitrage theory of capital asset pricing, Journal of Economics Theory, vol.13, pp.341-360, (1976). 